\title{
Evaluation of Leaf Properties of Eight Cherry Cultivars Grafted onto Maxma 14 Rootstock
}

\author{
Servet Aras (Corresponding author) \\ Faculty of Agriculture, Department of Horticulture, Yozgat Bozok University \\ PO Box 66200, Yozgat, Turkey \\ E-mail: servet.aras@bozok.edu.tr \\ Hakan Keles \\ Faculty of Agriculture, Department of Horticulture, Yozgat Bozok University \\ PO Box 66200, Yozgat, Turkey \\ E-mail: hakan.keles@bozok.edu.tr
}

Received: July 11, 2019

Accepted: August 1, 2019 Published: August 14, 2019

doi:10.5296/jas.v7i3.15270

URL: https://doi.org/10.5296/jas.v7i3.15270

\begin{abstract}
The study was conducted in order to assess the leaf properties of different sweet cherry varieties grafted onto MaxMa 14 rootstock. The experiment was arranged in a randomized plot desing with three replicates of five plants per replication. The soil analyses showed that the soil properties of experiment site were found as moderate alkaline, low amount of organic material, N, P, Zn and Mn. The soil characteristics may be sub-optimum for cherry growing. According to our results, Kordia had the highest SPAD value (37.86) among the cultivars. Samba, Regina, Kordia and 0900 Ziraat cultivars had the highest anthocyanin contents. The highest stomatal conductance was in 0900 Ziraat cv followed by Sweetheart. Samba had greater leaf area $(53.25 \mathrm{~cm} 2)$ compared to other cultivars. The highest LRWC was obtained with Lorry Bloom. Epicuticular was content of Regina leaves was higher among the cultivars. The results of the present study provide useful informations about how the cherry scions grafted onto MaxMa 14 response to environmental challenges in nature. The identified leaf properties are valuable targets for physiological studies related with environmental stresses.
\end{abstract}

Keywords: cherry, leaf properties, MaxMa 14, scion, variety

\section{Introduction}

Sweet cherry (Prunus avium L.) is one of the most economically important fruit worldwide 
growing in temperate climate zones. Sweet cherry production in world increased from 1.9 to 2.32 million tons over the last 16 years (Blando and Oomah, 2019). Establishing a cherry orchard represents a 20-25-year economic value. Cultivar and rootstock selections are pivotal factors affecting orchard profitability. Several different rootstocks are used in cherry orchards. This is mainly due to the environmental stress factors adversely affect plant growth. Many studies reveal that the use of stress tolerant rootstocks can help scion to survive under stress conditions (Aras and Eşitken, 2018, 2019b; Li et al., 2019). Scions are also important due to affecting stress tolerance, fruit quality and yield and consequently, the property of economy. Therefore, the choice of a cultivar by growers is other important key decision in the economy of the region.

Canopy of cultivars affects light distribution and consequently photosynthesis. Tree vigor depending on scion-rootstock interactions influences fruit yield, precocity and tree management costs (Lordan et al., 2017). In addition, scion-rootstock interactions modify the tolerance to many environmental stresses. Plant leaves can be used as an indicator of stress damage (Wahome et al., 2001) and also affect photosynthesis (Wu et al., 2019). Increase in photosynthesis leads to improve in fruit yield and quality. Many physiological and biochemical responses occur in the leaves during vegetation. Leaves reflect plant status under different environmental conditions. Chlorophyll content of the leaves is key component of the photosynthesis (Mehta et al., 2010). Leaf water content is also a determiner of photosynthesis (Garriga et al. 2015). The epicuticular wax other important leaf characteristic is an effective barrier to water loss. Moreover, the waxes repel bacterial and fungal pathogens and prevent excess UV radiation (Jenks et al., 1994; Krauss et al., 1997). In a previous study, two plum cultivars budded on some rootstocks were evaluated under Mediterranean conditions. Many leaf properties such as chlorophyll and leaf mineral content changed depending on cultivar and rootstock interaction (Reig et al., 2018). Nikolopoulos et al. (2002) stated that alterations in leaf anatomy and morphology of cherry contribute to photosynthetic capacity. Furthermore, it has been reported that morpho-anatomy, chemical composition, gas exchange and water status of sweet cherry leaves varied under different growth habits such as open and dense canopy conditions (Gonçalves et al., 2008).

To improve adaptability to environmental challenges, different cultivars can be used. Most of the studies evaluated the rootstock ability to environmental conditions, however few studies offer the choice of cultivar. The main objective of this study was to evaluate some leaf properties of eight of the most popular sweet cherries grafted onto MaxMa 14 rootstock.

\section{Materials and Methods}

\subsection{Plant material, Site Description and Experimental Design}

The study was carried out during two growing season of 2018-2019 at the Yozgat Bozok University Experiment Orchard. Six year old sweet cherry cultivars Samba, Regina, Kordia, Karina, Early Lory, 0900 Ziraat, Sweetheart and Lorry Bloom grafted onto MaxMa 14 rootstock were compared. The rootstock was chosen because it is semi-dwarfing (Moreno et al., 2001) and common rootstock for sweet cherry in Turkey. Starks Gold was planted in the orchard as pollinator. The experiment was arranged in a randomized plot desing with three replicates of five 
plants per replication. Tree spacing was $4 \mathrm{~m} \times 5 \mathrm{~m}$. Trees were irrigated through drip lines as needed. Average annual precipitation for the region was $554 \mathrm{~mm}$. Tree training was based on encouraging development of the leader. Soil properties are shown in Table 1.

Table 1. Soil properties of experiment site (Balcı and Yakupoğlu, 2018)

\begin{tabular}{|c|c|c|c|}
\hline Property & Amount & Property & Amount \\
\hline $\mathrm{pH}$ & 7.91 & $\mathrm{Ca}, \quad \mu \mathrm{g} \mathrm{g}^{-1}$ & 7561 \\
\hline Salt, \% & 0.021 & $\mathrm{Mg}, \quad \mu \mathrm{g} \mathrm{g}^{-1}$ & 167 \\
\hline $\mathrm{CaCO}_{3}, \%$ & 5.36 & Fe, $\quad \mu g g^{-1}$ & 2.05 \\
\hline Organic material, $\%$ & 0.99 & $\mathrm{Cu}, \quad \mu \mathrm{g} \mathrm{g}^{-1}$ & 0.42 \\
\hline Total N, \% & 0.05 & $\mathrm{Zn}, \quad \mu \mathrm{g} \mathrm{g}^{-1}$ & 0.29 \\
\hline $\mathrm{P}, \quad \mu \mathrm{g} \mathrm{g}^{-1}$ & 5.76 & $\mathrm{Mn}, \quad \mu \mathrm{g} \mathrm{g}^{-1}$ & 4.44 \\
\hline $\mathrm{K}, \quad \mu \mathrm{g} \mathrm{g}^{-1}$ & 215 & & \\
\hline
\end{tabular}

\subsection{Leaf Properties}

Relative chlorophyll value (SPAD) was measured with a Minolta SPAD-502 chlorophyll meter (Minolta Camera Co, Ltd, Osaka, Japan). Relative anthocyanin content of the leaves was measured with an Anthocyanin Content Meter (ACM-200 plus). Stomatal conductivity and leaf temperature were measured with a leaf porometer (Li-COR). Measurement of leaf area was performed with a leaf area meter.

Leaf relative water content (LRWC) was determined by the procedure of Smart and Bingham (1974). Fresh weights (FW) of leaves were determined and then leaves were placed in distilled water to rehydrate. After 5 hours, turgid weights (TW) were determined. Afterward, leaves were oven-dried and dry weights (DW) were determined. LRWC was calculated using the equation as:

$$
\operatorname{LRWC}(\%)=[(\mathrm{FW}-\mathrm{DW}) /(\mathrm{TW}-\mathrm{DW})] \times 100
$$

To determine epicuticular wax content, total leaf area of leaf samples was determined with a leaf area meter and the leaves were weighed. Wax removal was done by dipping 50 leaves in chloroform $(\mathrm{CHCl} 3)$ for $30 \mathrm{~s}$. After removing the wax, leaves were weighed and total wax concentration calculated on a leaf area basis $\left(\mu \mathrm{g} / \mathrm{cm}^{2}\right)$ (Alcerito et al., 2002).

SPSS software (20.0) was used to perform the statistical analyses. Average of the data belonging two consecutive years was analyzed. Significance was determined at the $5 \%$ level by the Duncan's test. 


\section{Results}

Leaf properties were significantly affected by cultivar. Table 2 and 3 represents the mean value of the leaf properties affected by MaxMa 14 rootstock evaluated in the current work over two years (2018-2019).

Kordia had the highest SPAD value (37.86) among the cultivars. Samba, Regina, Kordia and 0900 Ziraat cultivars had the highest anthocyanin contents. Stomatal conductance varied from 106.56 to $168.96 \mathrm{mmol} \mathrm{m}^{-2} \mathrm{~s}^{-1}$ and the highest value was in 0900 Ziraat $\mathrm{cv}$ followed by Sweetheart. Leaf temperature was not significantly different among cultivars.

Table 2. SPAD, anthocyanin, stomatal conductance and leaf temperature values of cultivars

\begin{tabular}{lllll}
\hline Cultivars & SPAD & Anthocyanin & $\begin{array}{l}\text { Stomatal conductance } \\
\left(\mathrm{mmol} \mathrm{m}^{-2} \mathrm{~s}^{-1}\right)\end{array}$ & $\begin{array}{l}\text { Leaf } \\
\text { temperature }\left({ }^{\circ} \mathrm{C}\right)\end{array}$ \\
\hline Samba & $35.63 \mathrm{abc}$ & $4.90 \mathrm{a}$ & $145.83 \mathrm{ab}$ & $30.06 \mathrm{NS}$ \\
Regina & $33.53 \mathrm{bcd}$ & $4.90 \mathrm{a}$ & $135.10 \mathrm{ab}$ & 30.36 \\
Kordia & $37.86 \mathrm{a}$ & $4.63 \mathrm{a}$ & $117.33 \mathrm{ab}$ & 31.40 \\
Karina & $30.23 \mathrm{e}$ & $4.00 \mathrm{~b}$ & $125.06 \mathrm{ab}$ & 28.76 \\
Early Lory & $32.50 \mathrm{de}$ & $3.73 \mathrm{~b}$ & $106.56 \mathrm{~b}$ & 30.10 \\
0900 Ziraat & $35.93 \mathrm{ab}$ & $4.70 \mathrm{a}$ & $168.96 \mathrm{a}$ & 31.50 \\
Sweetheart & $33.03 \mathrm{~cd}$ & $4.00 \mathrm{~b}$ & $160.46 \mathrm{a}$ & 31.46 \\
Lorry Bloom & $30.33 \mathrm{e}$ & $3.83 \mathrm{~b}$ & $151.93 \mathrm{ab}$ & 31.70 \\
\hline
\end{tabular}

Means separation within the columns and line by Duncan's multiple range test $(\mathrm{P}<0.05)$. NS-Non-Significant

Samba had greater leaf area $\left(53.25 \mathrm{~cm}^{2}\right)$ compared to other cultivars. The highest LRWC was obtained with Lorry Bloom. Epicuticular was content of Regina leaves was higher among the cultivars (Table 3). 


\section{Macrothink

Table 3. Leaf area, LRWC and epicuticular wax content values of cultivars

\begin{tabular}{|c|c|c|c|}
\hline Cultivars & $\begin{array}{l}\text { Leaf area } \\
\left(\mathrm{cm}^{2}\right)\end{array}$ & LRWC (\%) & $\begin{array}{l}\text { Epicuticular wax } \\
\text { content }\left(\mu \mathrm{g} / \mathrm{cm}^{2}\right)\end{array}$ \\
\hline Samba & $53.25 \mathrm{a}$ & $80.27 \mathrm{~b}$ & $434.29 \mathrm{ab}$ \\
\hline Regina & $36.46 \mathrm{~b}$ & $79.48 \mathrm{bc}$ & $556.61 \mathrm{a}$ \\
\hline Kordia & $39.00 \mathrm{~b}$ & $76.68 \mathrm{bc}$ & $479.17 \mathrm{ab}$ \\
\hline Karina & $41.95 \mathrm{~b}$ & $79.24 \mathrm{bc}$ & $431.38 \mathrm{ab}$ \\
\hline Early Lory & $34.96 \mathrm{~b}$ & $75.74 \mathrm{c}$ & $283.54 \mathrm{~b}$ \\
\hline 0900 Ziraat & $39.08 \mathrm{~b}$ & $76.73 \mathrm{bc}$ & $402.34 \mathrm{ab}$ \\
\hline Sweetheart & $36.50 \mathrm{~b}$ & $77.48 \mathrm{bc}$ & $299.47 \mathrm{~b}$ \\
\hline Lorry Bloom & $36.96 \mathrm{~b}$ & $84.28 \mathrm{a}$ & $456.48 \mathrm{ab}$ \\
\hline
\end{tabular}

Means separation within the columns and line by Duncan's multiple range test $(\mathrm{P}<0.05)$. NS-Non-Significant

\section{Discussion}

Plants are exposed to many environmental challenges such as drought, low temperature and salinity. In the current study we corroborated the leaf properties of six-year old sweet cherry cultivars grafted onto MaxMa 14 rootstock. Leaves reflect plant status under different environment conditions. Therefore, we measured and compared many properties of leaves in order to determine the status of sweet cherry plants in temperate zone. Moreover, the soil analyses showed that the soil properties of experiment site were found as moderate alkaline, low amount of organic material, $\mathrm{N}, \mathrm{P}, \mathrm{Zn}$ and $\mathrm{Mn}$. The soil characteristics may be sub-optimum for cherry growing.

SPAD value indicates relative chlorophyll content and chlorophyll takes central role in the photosynthesis. Chlorophyll reduction due to the environmental stresses has been stated for several species (Aras and Eşitken, 2019a, b; Civelek and Yıldırım, 2019). Kordia had the highest SPAD value observed as more greenness of leaves among varieties while Karina and Lorry Bloom had the lowest value. Reig et al. (2018) evaluated two plum cultivars under Mediterranean conditions and SPAD value of the cultivars grafted onto two different rootstock ranged from 30.9 to 34.2. Anthocyanins, as well as chlorophyll, are pigments responsible in photosynthesis and red coloration of leaves. Plants accumulate anthocyanins as an adaptive response to capture more light (Gould et al. 1995). Moreover, anthocyanins can protect plants from stress factors (Gitelson et al., 2001). In our experiment Samba, Regina, 
Kordia and 0900 Ziraat had higher anthocyanin content.

Stomata take a pivotal role in the $\mathrm{CO}_{2}$ and $\mathrm{O}_{2}$ exchange and regulate leaf water status (Arbona et al., 2005). Lower stomatal conductance represents decrease in photosynthesis related with gas exchange and indicates avoiding water loss through stomatal closure. This phenomenon is likely related to less leaf transpiration via stomata. Many experiments demonstrated that plants close stomatal gaps in order to decrease water loss under stresses (García-Legaz et al., 2008; Aras and Eşitken, 2018). 0900 Ziraat and Sweetheart tended to have higher stomatal conductance. In a study of Gonçalves et al. (2008), stomatal conductances of Burlat, Summit and Van sweet cherry cultivars grafted onto Edabriz were 119, 157 and $176 \mathrm{mmol} \mathrm{m}^{-2} \mathrm{~s}^{-1}$, respectively.

Leaf, a plant part, captures solar energy for photosynthesis. Therefore, plant productivity depends on the leaf area (Turner and Begg, 1981). Plants adjust leaf size as an adaptive mechanism to drought conditions (Liu and Stützel, 2004). Thus, leaf area depends on the environmental conditions. In our work, Samba had higher leaf area compared to other cultivars. In other work, it was found leaf area of Burlat, Summit and Van sweet cherry cultivars ranged from 52.6 to $75.7 \mathrm{~cm}^{2}$ (Gonçalves et al., 2008).

Leaf water content influences photosynthesis and plants exhibit some protective ways to avoid water loss. Stomata closure and epicuticular wax formation are defense mechanisms to save water in the leaves against environmental challenges. In the current study in Early Lory had the lowest LRWC, while this variety had the lowest stomatal conductance. Decrease in LRWC despite stomatal closure may be due to possessing lower epicuticular waxes on the leaf surface. Leaves contain wax layer in epicuticula. Environmental conditions affect epicuticular wax content (Maiti et al., 2016). Epicuticular wax reduces radiation and cuticular transpiration as an adaptation to stress conditions (Mohammadian et al., 2007). Many studies showed that epicuticular wax decreases water loss from leaves and thus contribute drought tolerance (Figueiredo et al., 2015; Medeiros et al., 2017). We determined wax content of eight cherry cultivars and Regina had the highest wax content while the lowest values were found in Early Lorry and Sweetheart. Furthermore, Early Lorry and Sweetheart had lower LRWC among the cultivars that may be a result of low epicuticular wax content.

\section{Conclusion}

We determined the leaf properties of the different sweet cherry varieties grafted onto MaxMa 14 rootstock under sub-optimum soil characteristics. The results of the present study provide useful information about how the cherry scions grafted onto MaxMa 14 response to environmental challenges in nature. The choice of an appropriate scion is an effective way to overwhelm environmental stresses. The findings of this study could be beneficial for plant physiologists working on abiotic stresses. In terms of stomatal conductance, Early Lory adapted well under the soil and climate conditions. Under drought and water limited conditions, Early Lory should be recommend to growers due to lower stomatal conductance as an adaptive mechanism to environmental challenges. 


\section{References}

Alcerito, T., Barbo, F. E., Negri, G., Santos, D. Y., Meda, C. I., Young, M. C. M., ... \& Blatt, C. T. (2002). Foliar epicuticular wax of Arrabidaea brachypoda: flavonoids and antifungal activity. Biochemical Systematics and Ecology, 30(7), 677-683.

https://doi.org/10.1016/S0305-1978(01)00149-1

Aras, S., \& Eşitken, A. (2018). Physiological Responses of Cherry Rootstocks to Short Term Salinity. Erwerbs-Obstbau, 60(2), 161-164. https://doi.org/10.1007/s10341-017-0350-x

Aras, S., \& Eşitken, A. (2019a). Responses of Apple Plants to Salinity Stress. Yüzüncü Yll University Journal of Agricultural Science, 29(2), 253-257.

https://doi.org/10.29133/yyutbd.494677

Aras, S., \& Eşitken, A. (2019b). Responses of Cherry Plant Grafted onto CAB-6P, MaxMa 14 and Mazzard Rootstocks to Short Term Salinity. Journal of Agricultural Studies, Accepted. https://doi.org/10.5296/jas.v7i3.15114

Arbona, V., Iglesias, D. J., Jacas, J., Primo-Millo, E., Talon, M., \& Gomez-Cadenas, A. (2005). Hydrogel substrate amendment alleviates drought effects on young citrus plants. Plant and Soil, 270, 73-82. https://doi.org/10.1007/s11104-004-1160-0

Balc1, G., \& Yakupoğlu, T. (2018). Soil Compaction in A Small Berry Garden Established in A Semi-Arid Region. Turkish Journal of Agriculture-Food Science and Technology, 6(10), 1412-1418. https://doi.org/10.24925/turjaf.v6i10.1412-1418.2050

Blando, F., \& Oomah, B. D. (2019). Sweet and Sour Cherries: Origin, Distribution, Nutritional Composition and Health Benefits. Trends in Food Science \& Technology, 86, 517-529. https://doi.org/10.1016/j.tifs.2019.02.052

Civelek, C., \& Y1ldırım, E. (2019). Effects of Exegenous Glycine Betaine Treatments on Growth and Some Physiological Characteristics of Tomato under Salt Stress Condition. Atatürk University Ziraat Fakültesi Dergisi, 50(2), 153-158.

https://doi.org/10.17097/ataunizfd.520407

Figueiredo, K. V., Oliveira, M. T., Arruda, E. C., Silva, B. C., \& Santos, M. G. (2015). Changes in leaf epicuticular wax, gas exchange and biochemistry metabolism between Jatropha mollissima and Jatropha curcas under semi-arid conditions. Acta physiologiae plantarum, 37(6), 108. https://doi.org/10.1007/s11738-015-1855-2

García-Legaz, M. F., López-Gómez, E., Beneyto, J. M., Navarro, A., \& Sánchez-Blanco, M. J. (2008). Physiological behaviour of loquat and anger rootstocks in relation to salinity and calcium addition. Journal of Plant Physiology, 165(10), 1049-1060.

https://doi.org/10.1016/j.jplph.2007.07.022

Garriga, M., Muñoz, C. A., Caligari, P. D., \& Retamales, J. B. (2015). Effect of salt stress on genotypes of commercial (Fragaria X ananassa) and Chilean strawberry (F. chiloensis). Scientia Horticulturae, 195, 37-47. https://doi.org/10.1016/j.scienta.2015.08.036 
Gitelson, A. A., Merzlyak, M. N., \& Chivkunova, O. B. (2001). Optical properties and nondestructive estimation of anthocyanin content in plant leaves. Photochemistry and Photobiology, 74(1), 38-45.

https://doi.org/10.1562/0031-8655(2001)074<0038:OPANEO>2.0.CO;2

Gonçalves, B., Correia, C. M., Silva, A. P., Bacelar, E. A., Santos, A., \& Moutinho-Pereira, J. M. (2008). Leaf structure and function of sweet cherry tree (Prunus avium L.) cultivars with open and dense canopies. Scientia Horticulturae, 116(4), 381-387.

https://doi.org/10.1016/j.scienta.2008.02.013

Gould, K. S., Kuhn, D. N., Lee, D.W., \& Oberbauer, S. F. (1995). Why leaves are sometimes red. Nature, 378, 241-242. https://doi.org/10.1038/378241b0

Jenks, M. A., Joly, R. J., Peters, P. J., Rich, P. J., Axtell, J. D., \& Ashworth, E. N. (1994). Chemically induced cuticle mutation affecting epidermal conductance to water vapor and disease susceptibility in Sorghum bicolor (L.) Moench. Plant Physiology, 105(4), 1239-1245. https://doi.org/10.1104/pp.105.4.1239

Krauss, P., Markstadter, C., \& Riederer, M. (1997). Attenuation of UV radiation by plant cuticles from woody species. Plant, Cell and Environment, 20, 1079-1085.

https://doi.org/10.1111/j.1365-3040.1997.tb00684.x

Li, M., Guo, Z., Jia, N., Yuan, J., Han, B., Yin, Y., ... \& Zhao, S. (2019). Evaluation of eight rootstocks on the growth and berry quality of 'Marselan'grapevines. Scientia Horticulturae, 248, 58-61. https://doi.org/10.1016/j.scienta.2018.12.050

Liu, F., \& Stützel, H. (2004). Biomass partitioning, specific leaf area, and water use efficiency of vegetable amaranth (Amaranthus spp.) in response to drought stress. Scientia Horticulturae, 102(1), 15-27. https://doi.org/10.1016/j.scienta.2003.11.014

Lordan, J., Fazio, G., Francescatto, P., \& Robinson, T. (2017). Effects of apple (Malus $\times$ domestica) rootstocks on scion performance and hormone concentration. Scientia Horticulturae, 225, 96-105. https://doi.org/10.1016/j.scienta.2017.06.050

Maiti, R., Rodriguez, H. G., Gonzalez, E. A., Kumari, A., \& Sarkar, N. C. (2016). Variability in epicuticular wax in 35 woody plants in Linares, Northeast Mexico. Journal of Forest Research, 5(162), 2.

Medeiros, C. D., Falcão, H. M., Almeida-Cortez, J., Santos, D. Y. A. C., Oliveira, A. F. M., \& Santos, M. G. (2017). Leaf epicuticular wax content changes under different rainfall regimes, and its removal affects the leaf chlorophyll content and gas exchanges of Aspidosperma pyrifolium in a seasonally dry tropical forest. South African Journal of Botany, 111, 267-274. https://doi.org/10.1016/j.sajb.2017.03.033

Mehta, P., Jajoo, A., Mathur, S., \& Bharti, S. (2010). Chlorophyll a fluorescence study revealing effects of high salt stress on Photosystem II in wheat leaves. Plant Physiology and Biochemistry, 48(1), 16-20. https://doi.org/10.1016/j.plaphy.2009.10.006

Mohammadian, M. A., Watling, J. R., \& Hill, R. S. (2007). The impact of epicuticular wax on 
gas-exchange and photoinhibition in Leucadendron lanigerum (Proteaceae). Acta oecologica, 31(1), 93-101. https://doi.org/10.1016/j.actao.2006.10.005

Moreno, M. A., Adrada, R., Aparicio, J., \& Betrán, S. (2001). Performance of 'Sunburst'sweet cherry grafted on different rootstocks. The Journal of Horticultural Science and Biotechnology, 76(2), 167-173. https://doi.org/10.1080/14620316.2001.11511345

Nikolopoulos, D., Liakopoulos, G., Drossopoulos, I., \& Karabourniotis, G. (2002). The relationship between anatomy and photosynthetic performance of heterobaric leaves. Plant Physiology, 129(1), 235-243. https://doi.org/10.1104/pp.010943

Reig, G., Lordan, J., Sazo, M. M., Hoying, S., Fargione, M., Reginato, G., .. \& Robinson, T. (2019). Long-term performance of 'Gala', Fuji'and 'Honeycrisp'apple trees grafted on Geneva ${ }^{\circledR}$ rootstocks and trained to four production systems under New York State climatic conditions. Scientia Horticulturae, 244, 277-293.

https://doi.org/10.1016/j.scienta.2018.09.025

Turner, N. C., \& Begg, J. E. (1981). Plant-water relations and adaptation to stress. Plant and Soil, 58(1-3), 97-131. https://doi.org/10.1007/BF02180051

Turrell, F. M. (1946). Tables of surfaces and volumes of spheres and of prolate and oblate spheroids, and spheroidal coefficients. Univ. of California Press, Berkeley.

Wahome, P. K., Jesch, H. H., \& Grittner, I. (2001). Mechanisms of salt stress tolerance in two rose rootstocks: Rosa chinensis 'Major' and R. rubiginosa. Scientia Horticulturae, 87, 207-216. https://doi.org/10.1016/S0304-4238(00)00168-0

Wu, A., Hammer, G. L., Doherty, A., von Caemmerer, S., \& Farquhar, G. D. (2019). Quantifying impacts of enhancing photosynthesis on crop yield. Nature Plants, 5(4), 380-388. https://doi.org/10.1038/s41477-019-0398-8

\section{Copyright Disclaimer}

Copyright for this article is retained by the author(s), with first publication rights granted to the journal.

This is an open-access article distributed under the terms and conditions of the Creative Commons Attribution license (http://creativecommons.org/licenses/by/4.0/). 